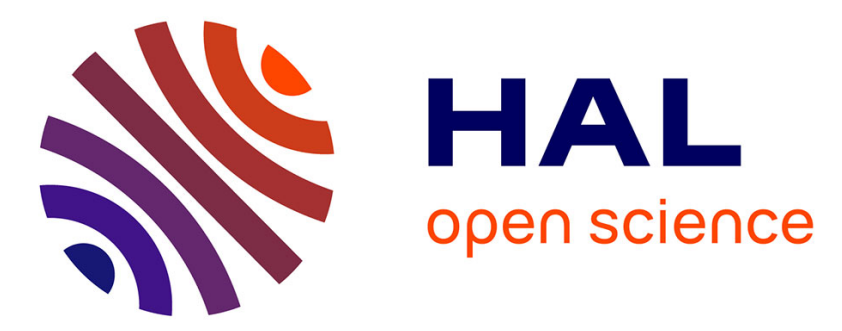

\title{
Improvement of Borehole Thermal Energy Storage Design Based on Experimental and Modelling Results
}

Sandra Lanini, Fabien Delaleux, Xavier Py, Régis Olivès, Denis Nguyen

\section{To cite this version:}

Sandra Lanini, Fabien Delaleux, Xavier Py, Régis Olivès, Denis Nguyen. Improvement of Borehole Thermal Energy Storage Design Based on Experimental and Modelling Results. Energy and Buildings, 2014, 20 p. 10.1016/j.enbuild.2014.03.056 . hal-00971602

\section{HAL Id: hal-00971602 https://hal-brgm.archives-ouvertes.fr/hal-00971602}

Submitted on 3 Apr 2014

HAL is a multi-disciplinary open access archive for the deposit and dissemination of scientific research documents, whether they are published or not. The documents may come from teaching and research institutions in France or abroad, or from public or private research centers.
L'archive ouverte pluridisciplinaire HAL, est destinée au dépôt et à la diffusion de documents scientifiques de niveau recherche, publiés ou non, émanant des établissements d'enseignement et de recherche français ou étrangers, des laboratoires publics ou privés. 


\title{
Improvement of Borehole Thermal Energy Storage Design Based on Experimental and Modelling Results
}

\author{
S. Lanini ${ }^{1}$, F. Delaleux ${ }^{2}$, X. Py ${ }^{3}$, R.Olivès ${ }^{3}$, D. Nguyen ${ }^{1}$ \\ ${ }^{1}$ BRGM, 1039 rue de Pinville, 34000 Montpellier, France, s.lanini@brgm.fr, tel:+33-467157964 \\ ${ }^{2}$ CERTES EA 3481- IUT de Sénart - université Paris Est Créteil - 36 rue Georges Charpak, 77127 Lieusaint, \\ France, fabien.delaleux@u-pec.fr \\ ${ }^{3}$ PROMES-CNRS UPR8521, University of Perpignan Via Domitia, Tecnosud 66100 Perpignan, France
}

\begin{abstract}
Underground Thermal Energy Storage appears to be an attractive solution for solar thermal energy storage. The SOLARGEOTHERM research project aimed to evaluate the energetic potential of borehole thermal energy storage by means of a full-scale experimental device and heat transfer models. Analysis of the experimental data showed that a single borehole is not efficient for storage. Application of a 1D analytical model showed that the heat transfer fluid in the geothermal probe lost 15 per cent of its energy at a depth of $100 \mathrm{~m}$ and 25 per cent at $150 \mathrm{~m}$. A 3D multilayer numerical model was then developed and validated against the experimental data. This model was then used to simulate different configurations over many years. Lastly, a theoretical approach to optimising design of a borehole thermal energy store (BTES) was proposed. A relation was established that enables comparison of the storage characteristic time of any vertical BTES to an optimum one. Based on these experimental, modelling and theoretical results, guidelines are formulated to optimise the design of vertical borehole fields with an objective of interseasonal heat storage. In particular, borehole fields should define cylindrical storage volumes with diameters twice their height, and depth should not exceed $100 \mathrm{~m}$.
\end{abstract}

\section{Keywords}

Energy storage, geothermal probe, heat transfers, modelling, BTES, dry rock, solar energy, SOLARGEOTHERM

\section{Highlights}

- Analysis of experimental data from a BTES comprising three $180 \mathrm{~m}$-deep boreholes. 
- Development of a 3D multilayer numerical model validated against experimental data.

- Long-term simulations of ground temperature behaviour in several BTES configurations.

- Theoretical relation to evaluate the storage performances of any cylindrical BTES.

\section{Nomenclature}

$\begin{array}{ll}\text { ATES } & \text { Aquifer Thermal Energy Storage } \\ \text { BTES } & \text { Borehole Thermal Energy Storage } \\ \mathrm{Cp} & \text { heat capacity, } \mathrm{J}_{\mathrm{kg}}{ }^{-1} \cdot \mathrm{K}^{-1} \\ \rho & \text { density, } \mathrm{kg} \cdot \mathrm{m}^{-3} \\ \lambda & \text { thermal conductivity, } \mathrm{W} \cdot \mathrm{m}^{-1} \cdot \mathrm{K}^{-1} \\ \mathrm{HDPE} & \text { High Density PolyEthylene } \\ \mathrm{HTF} & \text { Heat Transfer Fluid } \\ \mathrm{m} & \text { flow rate, } \mathrm{kg} \cdot \mathrm{s}^{-1} \\ \mathrm{r} & \text { radius, } \mathrm{m} \\ \mathrm{R} & \text { thermal resistance, } \mathrm{m} \cdot \mathrm{K} \cdot \mathrm{W}^{-1} \\ \mathrm{t} & \text { time, } \mathrm{s} \\ \mathrm{T} & \text { temperature, }{ }^{\circ} \mathrm{C} \text { or } \mathrm{K} \\ \mathrm{z} & \text { depth, } \mathrm{m} \\ \text { Subscript } & \\ b & \text { bentonite } \\ \text { in } & \text { inlet } \\ \text { ext } & \text { exterior } \\ \text { int } & \text { interior }\end{array}$

\section{Introduction}

Underground thermal energy storage (UTES) refers to systems that use buried devices designed to exchange heat with the surrounding ground. In geographic areas like Europe, where heating is needed in winter, the ground temperature is presumed to be lower than that of the heat source during the storage stage (summer) and higher during the discharge stage (winter), making UTES an apparently attractive 
solution for seasonal storage of solar thermal energy. Several storage devices are available, the choice of which depends on both the conditions of energy charging and discharging and on local geological and hydrogeological conditions [1]. For instance, heat may be stored in aquifers (ATES) or, conversely, in dry rock by circulating a fluid through a borehole thermal energy store (BTES). Numerous such sites are already operating in Canada and central and northern Europe where, combined with ground source heat pumps, they are providing block and district heating [2]. The design of an underground heat storage depends on the project context and designs are often developed on the basis of the results of numerical simulations. For example, Lundh \& Dalenbäck [3] report that to select the most effective design for the Anneberg project (Sweden), several combinations from 66 to 165 boreholes were simulated. The final solution comprises 100 boreholes inter-linked by a mixture of series and parallel connections. For the Drake Landing Solar Community project, in Okotoks (Canada), a radial flow pattern was preferred with a BTES field of 144 boreholes each $35 \mathrm{~m}$ deep [4]. For high quality air-conditioning of the Minhang archives building of Shanghai, Zhai and Yang [5] describe a ground source heat pump system based on a field of 280 vertical boreholes ( $80 \mathrm{~m}$ deep) with single U-tubes and parallel connections.

The SOLARGEOTHERM three-year, French research project that ended in 2012 focused on the study of solar thermal energy storage in dry rock. The aim of the project was optimisation and evaluation of the energy potential of BTES by use of a full-scale experimental device and heat transfer models. The SOLARGEOTHERM experimental site was located in a Paleozoic schist quarry in the eastern Pyrenees (France). It has been especially selected for its hydrogeological configuration, out of any known aquifer or groundwater flow. The static water level is $35 \mathrm{~m}$ deep. The experimental device included three subvertical boreholes drilled to a depth of $180 \mathrm{~m}$, spaced at $5 \mathrm{~m}$, and equipped with double- $U$ geothermal probes (32 mm outer diameter and $3 \mathrm{~mm}$ wall thickness). This heat storage device was charged via a hydraulic network circulating through $42 \mathrm{~m}^{2}$ of thermal solar panels; the heat transfer fluid (HTF) was water. The geothermal probes were instrumented with an optical fibre, enabling temperature monitoring throughout the boreholes with a sampling resolution of $1 \mathrm{~m}$, thanks to a Distributed Temperature Sensing device (Oryx DTS from Sensornet). Regarding the experimental context, absolute temperatures are 
given with an accuracy of $0.5^{\circ} \mathrm{C}$. Geological and fracturing characteristics of the bedrock were determined by cutting analysis and geophysical techniques (long and short resistivity, natural gamma, bore-hole imagery, etc.). As suggested by Fujii [6] and Acuna [7], vertical distribution of the bedrock's thermal properties was evaluated through an in-situ distributed thermal response test [8]. The resulting conductivity profile is presented on Figure 1. More details on the SOLARGEOTHERM experimental system can be found in [9]. Different modelling approaches and tools were applied to simulate heat transfers at different scales, in order to better ascertain the thermal functioning of the system.

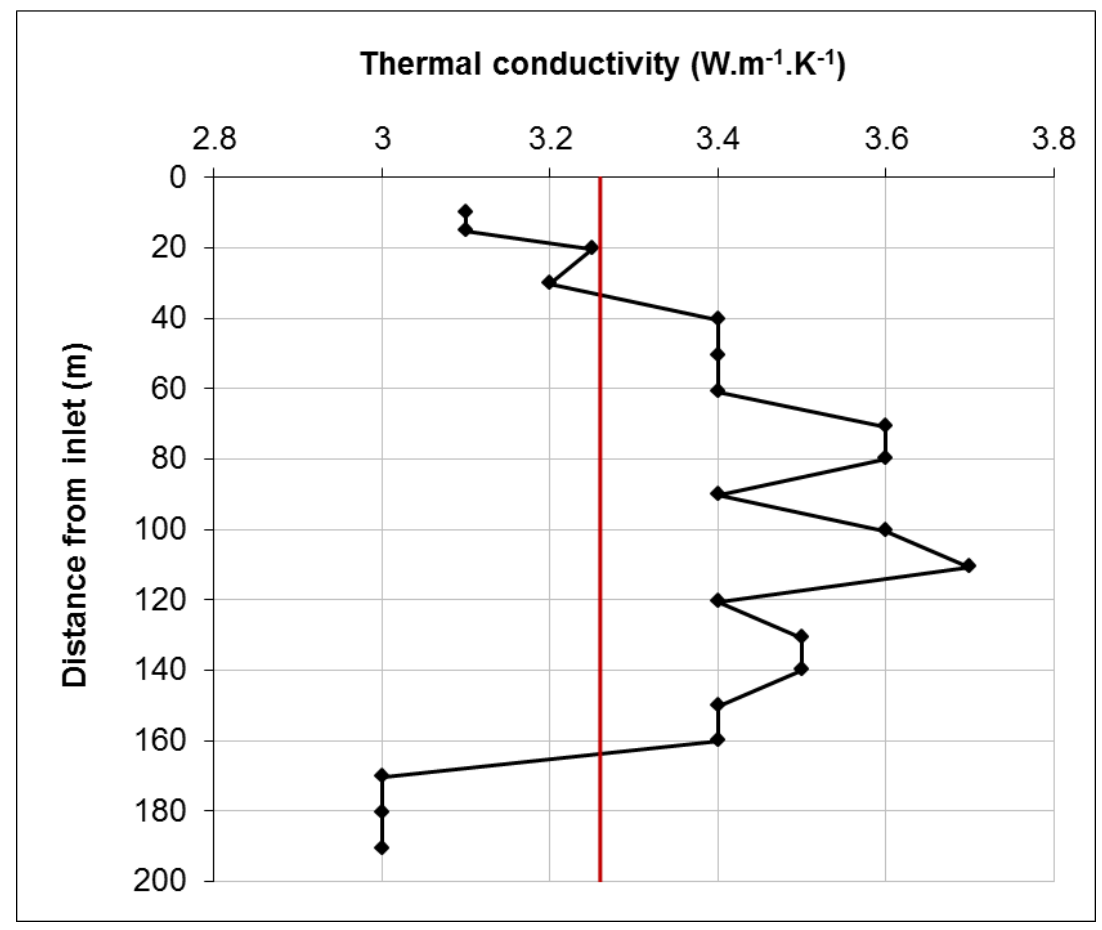

Figure 1: Thermal conductivity variation with depth as estimated thanks to the Distributed Thermal Response Test. The average value determined previously by a classical TRT (3.26 W.m-1.K-1) is also mentioned.

Heat injection into the experimental device was conducted with a flow rate of $32 \mathrm{l} / \mathrm{min}$. The $42 \mathrm{~m}^{2}$ solar panel plant is able to supply $32 \mathrm{~kW}$ at midday on a summer sunny day. Also, at a month scale, experimental data showed that about $5000 \mathrm{kWh}$ where injected in the ground during July 2010, with HTF temperature varying between 30 and $48^{\circ} \mathrm{C}$ (injection is automatically stopped when HTF temperature is lower than $30^{\circ} \mathrm{C}$ ). For comparison purposes, the energy extracted from the ground by a heat pump $(\mathrm{COP}=4)$ to heat a $100 \mathrm{~m}^{2}$ house over one year would be compensated by the solar plant in 3 months (case of a house with average energy needs, $150 \mathrm{kWh} \cdot \mathrm{m}^{-2}$.year ${ }^{-1}$ ) and even in 1 month for a low consumption house (50 
$\mathrm{kWh} \cdot \mathrm{m}^{-2}$.year ${ }^{-1}$ ). With normalized data, the energy given by $1 \mathrm{~m}^{2}$ of solar panel in one month in summer can cover the heat needs of $1 \mathrm{~m}^{2}$ of a house for one year (class $\mathrm{C}$ house) or even 3 years (low consumption house).

No energy recovery experiments were conducted during the first year, as the ground store needs to be heated to reach a yearly quasi steady state [10]. A technical failure in the injection device occurred after several months of operation, providing an unintended opportunity to observe ground thermal relaxation after a long injection period. When injection stopped, the underground temperature was observed to decrease progressively whatever the depth and to return to its initial state after only a few days (as an example, temperatures observed $180 \mathrm{~m}$ deep are reported on Figure 2). Clearly, this observation does not argue in favour of long-term energy storage in this experimental BTES, leading us to focus our analysis on the storage limits of the device. The results presented in this article were provided both by the experimental device and by the numerical models developed during the project.

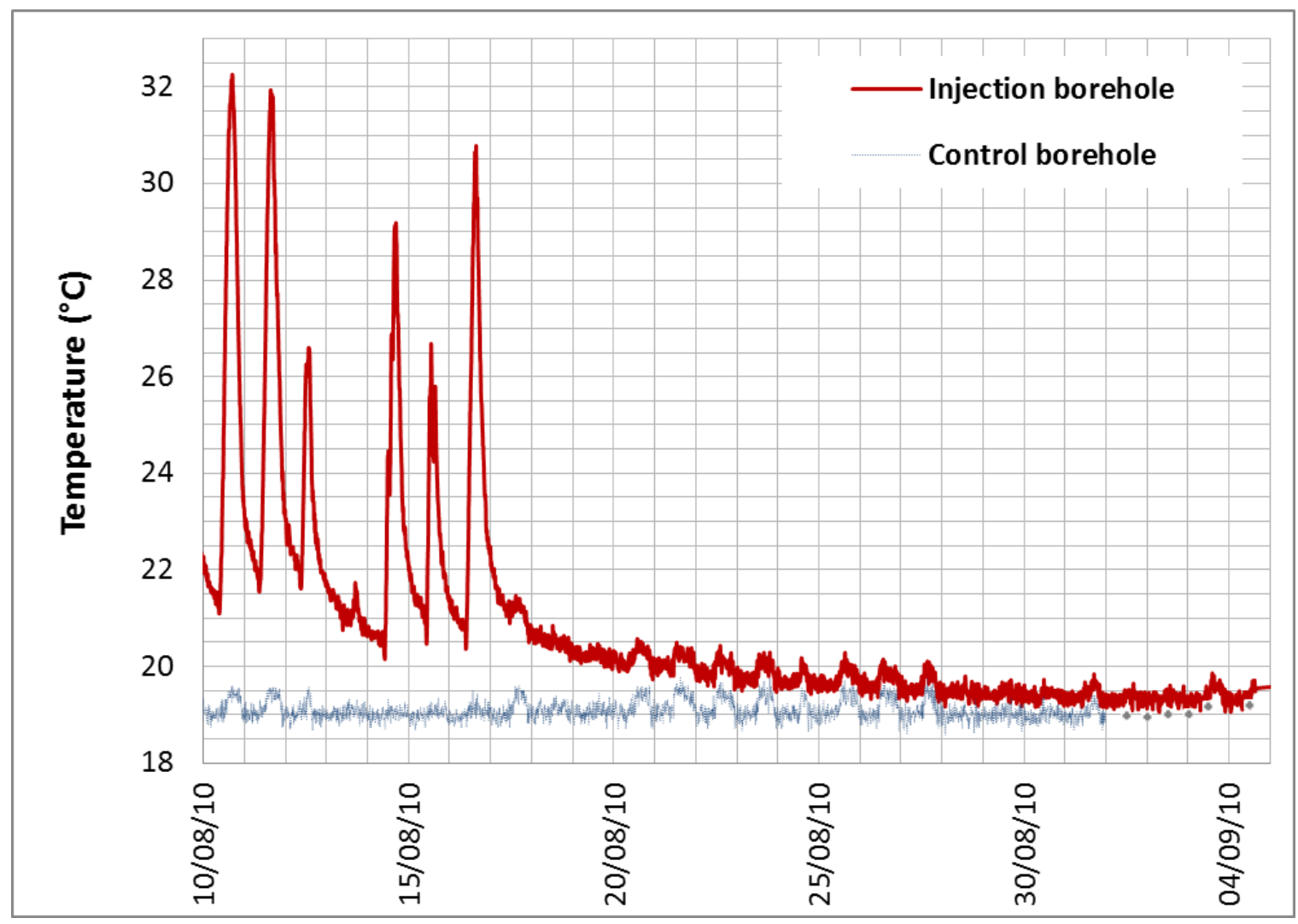

Figure 2: Evolution of temperature at the bottom of the injection borehole (depth $180 \mathrm{~m}$ ) during and after a summer period of significant heat injection in the experimental BTES (HTF temperature at the inlet of the borehole varies between $30^{\circ} \mathrm{C}$ and $43^{\circ} \mathrm{C}$ ). The control borehole $(5 \mathrm{~m}$ distant) shows an undisturbed ground temperature whatever the depth (including at $180 \mathrm{~m}$ as represented on the graph). The rapid temperature decrease in the injection borehole leads to return to the undisturbed state in less than 20 days. 


\section{Results}

\subsection{Experimental results}

In order to investigate the thermal behaviour of the surrounding soil, an initial experiment consisted of injection of heat via a single geothermal borehole. As mentioned above, HTF circulation was stopped accidentally after a significant injection period. Figure 2 shows the evolution of the rock temperature at that time (August 2010) at the bottom of the injection borehole and at the bottom of a control borehole (which represents the temperature of the undisturbed soil). During the injection period, the temperature at a depth of $180 \mathrm{~m}$ varied between 20 and $32{ }^{\circ} \mathrm{C}$, with daily variation patterns that relate to the variations in the thermal power delivered by the solar plant which has reached $32 \mathrm{~kW}$ at midday in summer. The temperature in the control borehole, filled with static water, was not affected by heat injection and remained constant at about $19^{\circ} \mathrm{C}$. When HTF circulation stopped, the borehole temperature decreased and reached its initial value, to within $0.5^{\circ} \mathrm{C}$, after six days. This result indicates that the major part of the heat injected via the borehole was quickly dissipated into the surrounding soil and it is concluded that a single borehole is not an efficient solution for inter-seasonal underground thermal energy storage. In order to evaluate efficiency over a shorter period, we calculated the ratio between the temperature decrease during a night and the temperature increase during the previous day, throughout the injection borehole and for a representative day of heat injection. The results are presented in Figure 3. They show that, all along the geothermal probe, about 95 per cent of the heat injected into the probe over a day is dissipated into the surrounding soil during the following night. This behaviour, and the rapid return to initial temperature when HTF circulation stops, prove that most of the injected energy is lost. The single $180 \mathrm{~m}$ deep borehole is therefore not recommended for day/night underground energy storage. 


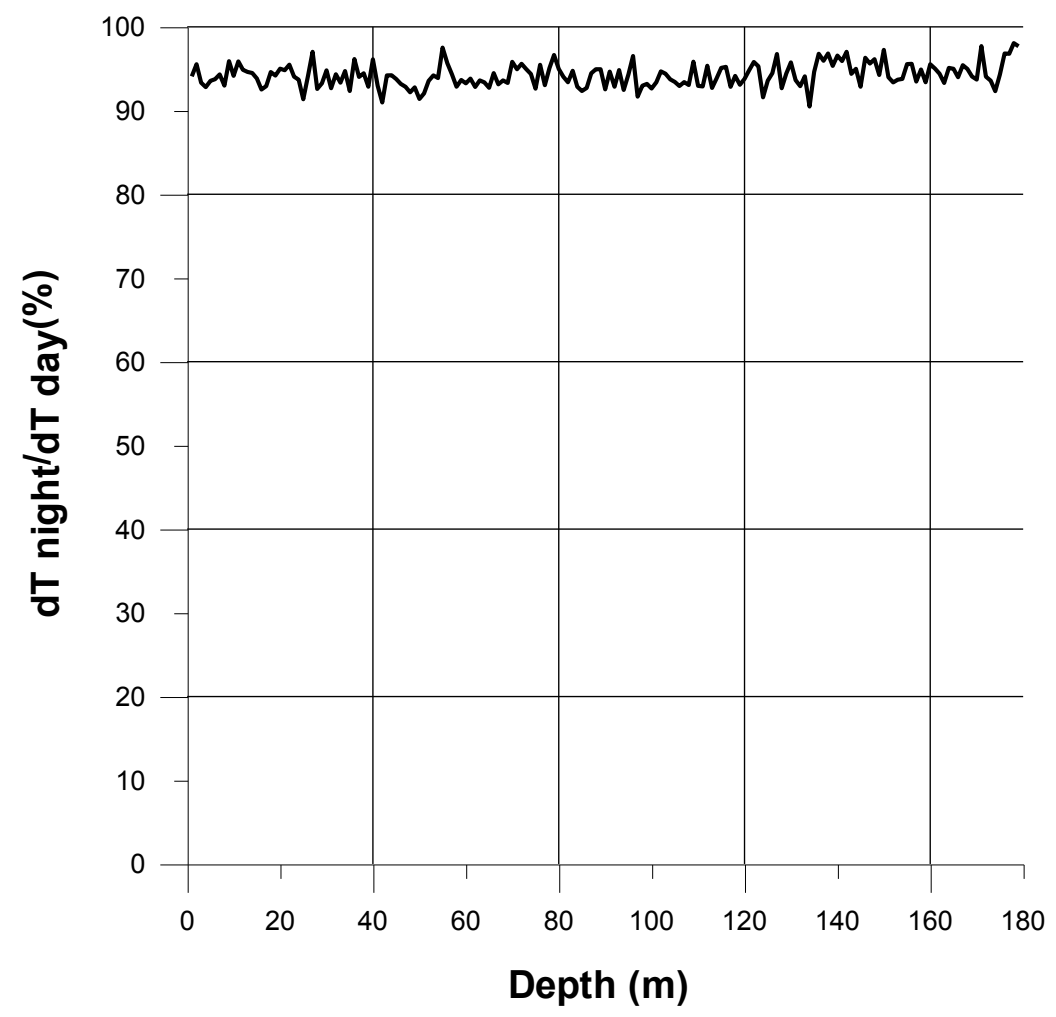

Figure 3: Evolution with depth of the ratio between the temperature variation during a night and the previous day. Temperature is measured on the single injection borehole for a representative summer injection day.

\section{$\underline{2.2 \text { Modelling results }}$}

Lamarche and Beauchamp [11] proposed an improved analytical model to describe heat transfers around ground heat exchangers. Later, Bauer et al. [12] explained that to describe heat transfers in a BTES device it is necessary to represent both vertical heat transport in the probes and horizontal heat diffusion into the different ground layers, taking account of the geothermal gradient. However, full 3D transient heat transfer modelling is particularly difficult to perform with regard to the borehole aspect ratio. Use of two coupled numerical models is therefore often preferred to study BTES. For instance, Mottaghy and Dijkshoorn [13] coupled a model of heat transfers in boreholes to a general heat and transport code. Sarbu and Sebarchievici recently proposed a review of models that can be applied to describe heat transfers separately inside the borehole and in the rock outside [14]. The SOLARGEOTHERM experimental BTES was modelled coupling a $1 \mathrm{D}$ analytical model and a $2 \mathrm{D}$ numerical model developed with the $\mathrm{COMSOL} \otimes$ software. The $1 \mathrm{D}$ analytical model calculates variations in HTF temperature with borehole depth. The $2 \mathrm{D}$ numerical model represents the thermal behaviour of the surrounding soil in $10 \mathrm{~m}$ thick layers, using results of the $1 \mathrm{D}$ model as boundary conditions in the borehole. The ground thermal 
properties imposed in each layer of the model correspond to the values evaluated by the enhanced geothermal response test. A 3D multilayer model is thereby made available.

2.2.1 Fluid temperature vertical distribution in the probe

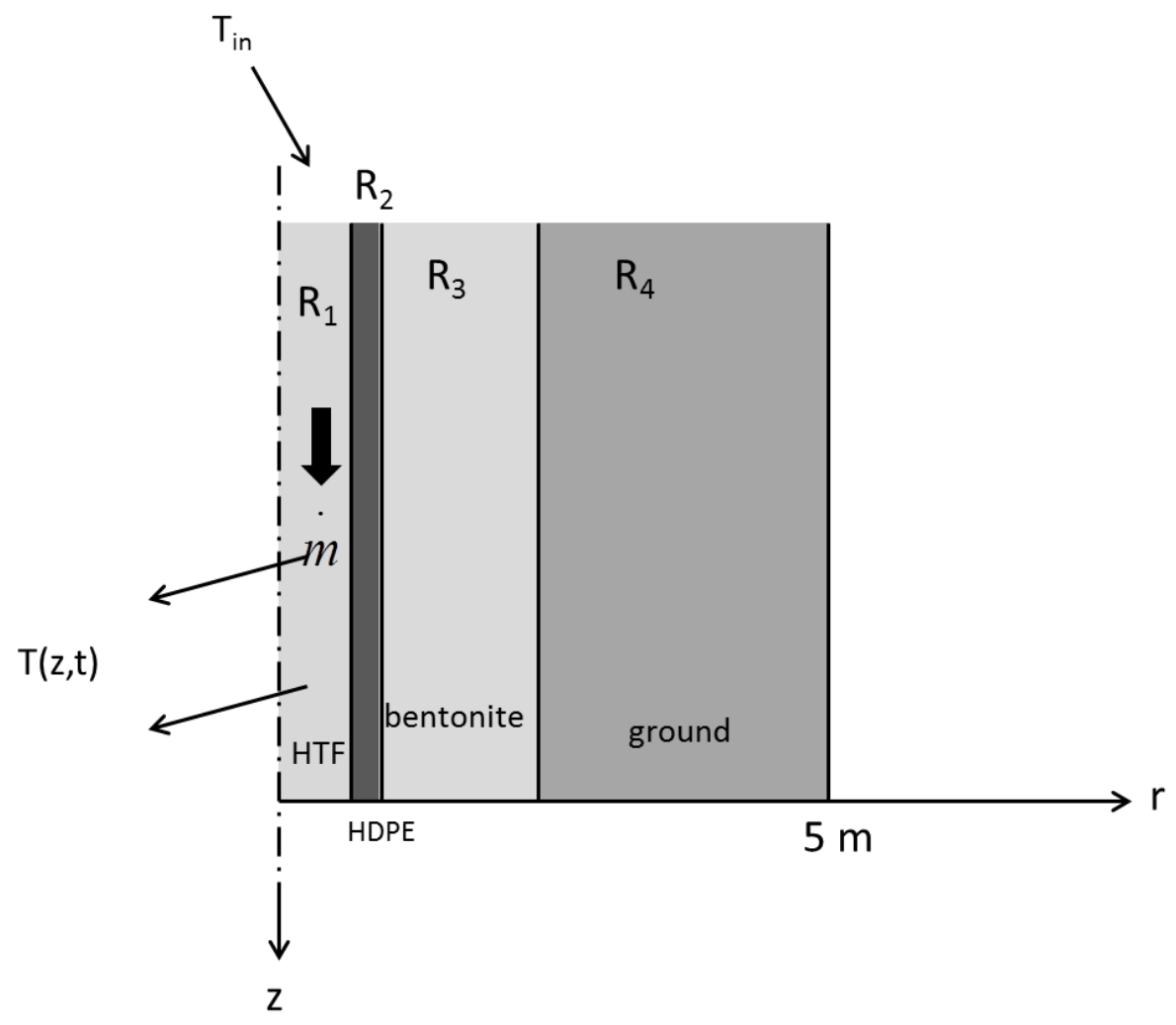

Figure 4: Geometry simulated by the 1D analytical model: a heat transfer fluid (HTF) flowing down in a cylindrical high density polyethylene (HDPE) geothermal probe separated from the ground with sealing grout.

The geometry taken into account for the 1D analytical model is illustrated in Figure 4. It represents HTF flowing down an HDPE geothermal probe that is separated from the ground by sealing grout.

The heat balance of the HTF is expressed as follows:

$T(z, t)=T_{\text {ground }}(z)+\left[T_{\text {in }}(t)-T_{\text {ground }}(z)\right] \cdot \exp \left[-z /\left(m^{\prime} \cdot C_{p} \cdot\left(R_{1}+R_{2}+R_{3}+R_{4}\right)\right]\right.$

where $T_{\text {ground }}(z)$ is the undisturbed ground temperature, $T_{\text {in }}(t)$ the water injection temperature, $\mathrm{m}^{\prime}$ the mass flow of $\operatorname{HTF}\left(\mathrm{kg} . \mathrm{s}^{-1}\right), \mathrm{C}_{\mathrm{p}}$ the heat capacity of water $\left(\mathrm{J} . \mathrm{kg}^{-1} . \mathrm{K}^{-1}\right), \mathrm{R}_{1}, \mathrm{R}_{2}, \mathrm{R}_{3}$ and $\mathrm{R}_{4}$ the thermal resistances of, respectively, the HTF, the HDPE, the grouting material and the ground $\left(m . K . W^{-1}\right) . R_{1}$ is related to the convective heat transfers between the water circulating in the probe and the probe itself. It was 
evaluated from the flow characteristics and the Nusselt number using the Colburn empirical correlation. The other three resistances relate to conductive transfers between the probe, the sealing grout and the rock:

$$
R_{1}=\frac{1}{2 \pi h_{H T F}} \quad R_{2}=\frac{\ln \frac{r_{\text {ext }}}{r_{\text {int }}}}{2 \pi \lambda_{H D P E}} \quad R_{3}=\frac{\ln \frac{r_{b}}{r_{\text {ext }}}}{2 \pi \lambda_{b}} \quad R_{4}=\frac{\ln \frac{r_{\text {ground }}}{r_{b}}}{2 \pi \lambda_{\text {ground }}}
$$

The values for the parameters used for calculations with the 1D model are given in Table 1. The equivalent thermal resistance $\left(R_{1}+R_{2}+R_{3}\right)$ of the underground thermal storage device is $0.19 \mathrm{~m} . \mathrm{K}_{\mathrm{W}} \mathrm{W}^{-1}$. Pahud and Matthey [15] have indicated that, in favourable cases, borehole thermal resistance could be reduced to $0.1 \mathrm{~m} . \mathrm{K}_{\mathrm{W}} \mathrm{W}^{-1}$. The water injection temperature varies with time in the model as the real inlet temperature measured on the experimental site.

The 1D analytical model gives the vertical distribution of HTF temperature in the borehole. As expected, HTF temperature is higher at the probe inlet than at a depth of $180 \mathrm{~m}$ : as the HTF gives up a part of its energy to the colder surrounding rock its temperature decreases with depth. The temperature difference between the HTF and the surrounding rock, calculated for a summer injection day at midday $\left(T_{\text {in }}(t)=48{ }^{\circ} \mathrm{C}\right.$, $\left.T_{\text {ground }}(10)=16{ }^{\circ} \mathrm{C}\right)$, is shown in Figure 5. Temperature decreases with depth from about $32{ }^{\circ} \mathrm{C}$ at $10 \mathrm{~m}$ to $23^{\circ} \mathrm{C}$ at $180 \mathrm{~m}$. Accordingly, the heat dissipated by the HTF decreases from about $76 \mathrm{~W} \cdot \mathrm{m}^{-1}$ at the inlet to $56 \mathrm{~W} \cdot \mathrm{m}^{-1}$ at the bottom of the geothermal probe. The injected heat rate is 25 per cent lower at a depth of $150 \mathrm{~m}$ than at the inlet to the geothermal probe. 


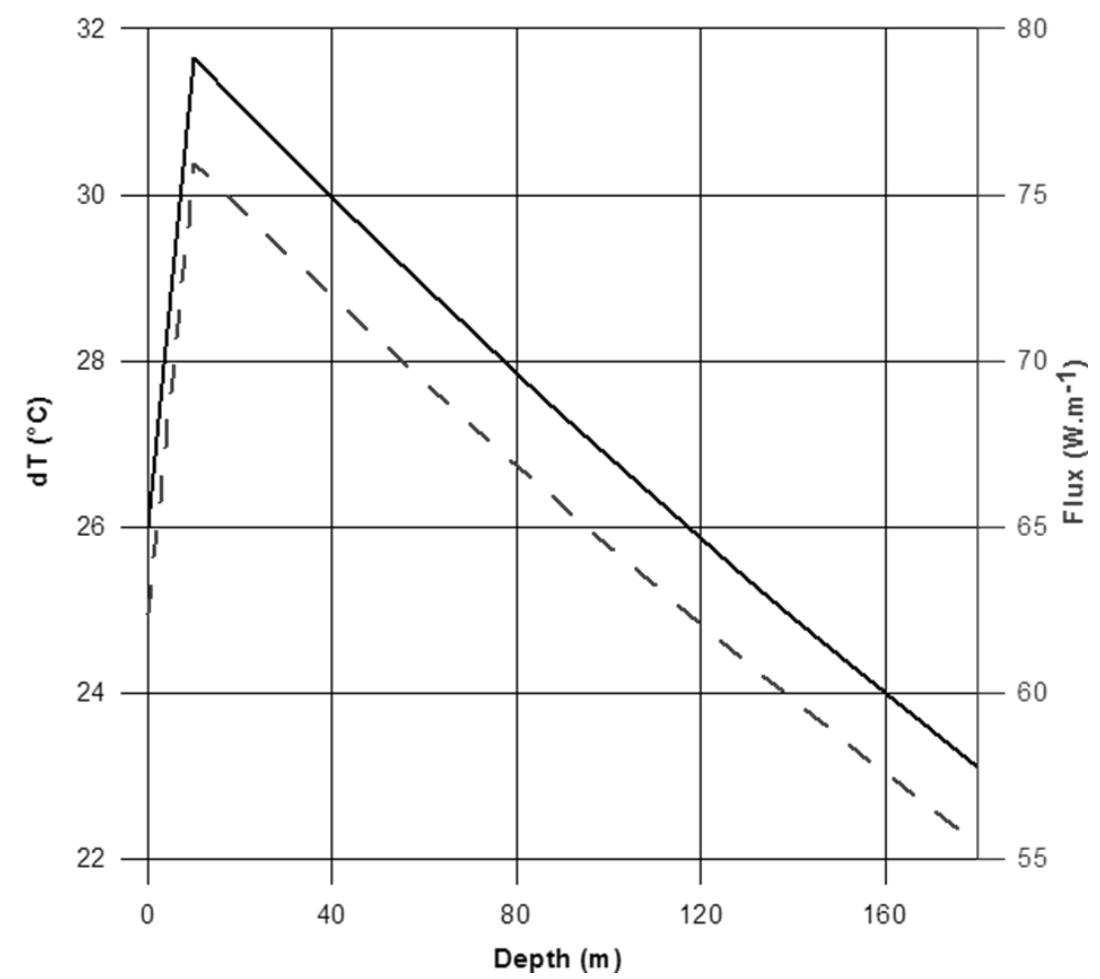

Figure 5: Variation with depth of the temperature difference between the fluid in the geothermal probe and the surrounding rock for a summer injection day (7 August 2010, at midday). Related variation of the dissipated heat rate per unit length.

\subsubsection{Ground temperature}

The distribution of ground temperature was simulated with a $2 \mathrm{D}$ numerical model developed with COMSOL. The HTF temperatures provided by the 1D model were applied as boundary conditions varying with depth. The geometry simulated by the 2D numerical model is shown in Figure 6, representing a cross-section of a borehole with the two double-U legs of the geothermal probe and the sealing grout.
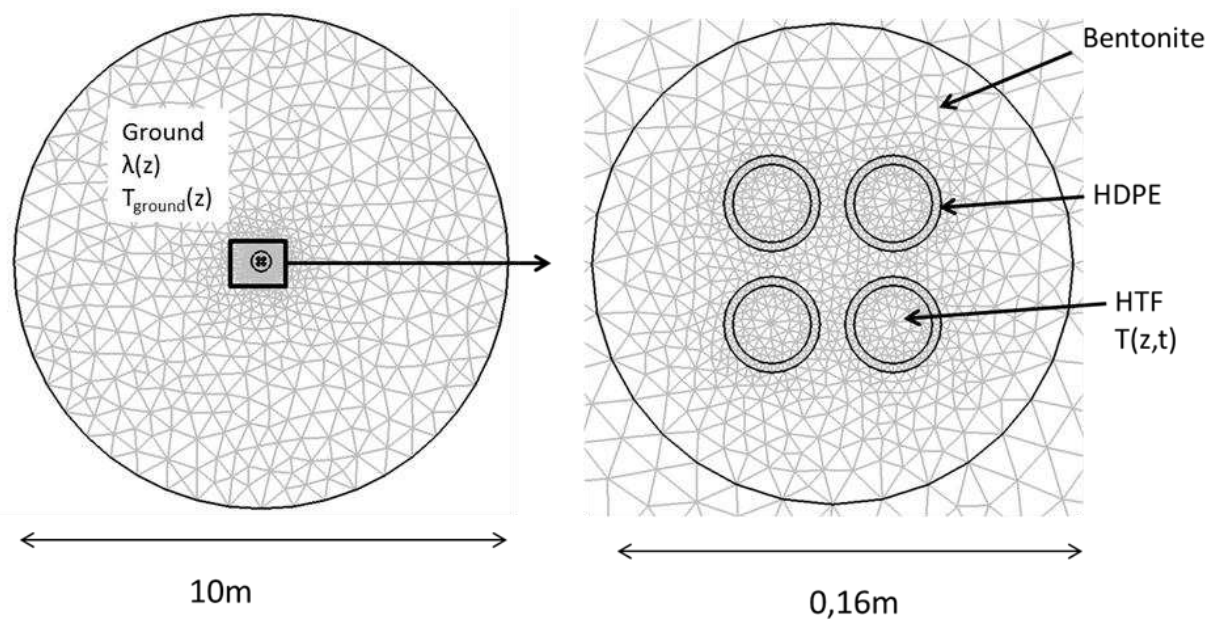

Figure 6: Geometry of the borehole simulated by the 2D numerical model. 
A cylindrical volume with a diameter of $10 \mathrm{~m}$ around the borehole is considered. Longest diameter was tested with no significant impact on the results, even when running long-term scenarios. This surrounding dry rock is divided into $10 \mathrm{~m}$ thick layers. The initial temperature variation with depth is given by the experimental data which were acquired before any thermal injection. Evolution of HTF temperature with time in each layer is applied in accordance with the results supplied by the 1D model. The thermal boundary condition is a no flux condition at the $10 \mathrm{~m}$ diameter circle, and at the bottom of the cylindrical volume. This 3D multilayer model was validated by comparison with the experimental data recorded during the heat injection summer period. For the double-U probe geometry, temperature varies all around the HDPE tube. Unfortunately, it is not possible to know exactly where the experimental temperatures were measured around the probe. Comparison is also made, for each depth, between the experimental value and the minimum and maximum calculated temperatures (Figure 7). The model's predictions appear to agree closely with observations. The model is therefore validated and can be used to investigate different heat injection configurations and to study the long term behaviour of the system.

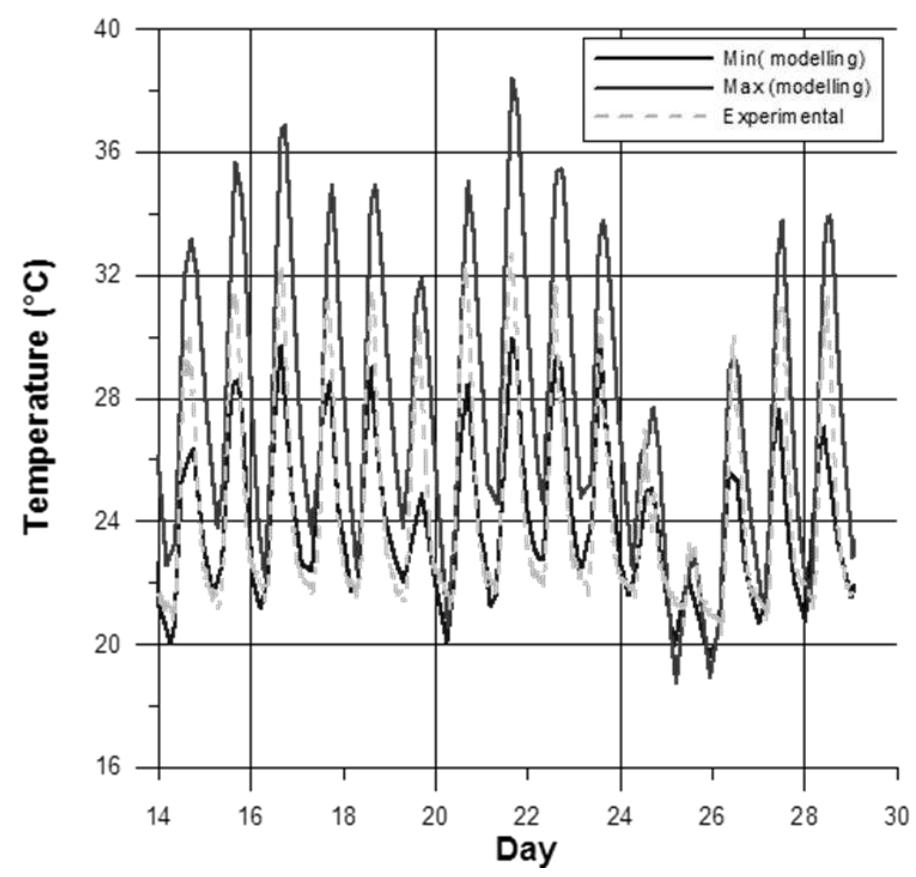

Figure 7: Simulated temperature at the bottom of the borehole (depth $180 \mathrm{~m}$ ) during the summer injection period (July 2010). Minimum and maximum values of temperature calculated around the HDPE tube are reported for each depth against experimental data.

The numerical model was run over many years, assuming continuous heat injection into the ground. The injected power varied during the day and over the year with 
sunshine levels, as it would if it had been collected by thermal panels. The heat was either injected into a single $180 \mathrm{~m}$ borehole or divided over three boreholes of equal depth. In each case, the system reached a stationary state in about one year. The heat injection impacted the ground temperature less than $5 \mathrm{~m}$ away from the probes. The final temperature increase in this $5 \mathrm{~m}$ diameter cylinder is in the range of 3 to $4{ }^{\circ} \mathrm{C}$ when the injected heat was concentrated in a single borehole and in the range of 2 to $3{ }^{\circ} \mathrm{C}$ when it was shared between three boreholes.

In greater detail, Figure 8a shows the simulated ground temperature at the centre of the three injection boreholes after a six-month injection period. The HTF temperature variations applied at the inlet of the geothermal probes correspond to real values measured at the outlet of the SOLARGEOTHERM solar plant. The $5 \mathrm{~m}$ distance between the vertical geothermal probes is constant with depth. Results are presented for every 30 metres of depth. It appears that after six months of heat injection, the highest ground temperature is observed at $30 \mathrm{~m}$ and the lowest at the borehole bottom $(180 \mathrm{~m})$. The temperature rises are not linear, a phenomenon relating to the boundary condition. After the six-month injection period, the temperature increases reach $7{ }^{\circ} \mathrm{C}$ at 30,60 and $90 \mathrm{~m}$ but only $3^{\circ} \mathrm{C}$ at $180 \mathrm{~m}$. However, the temperature level obtained appears nonetheless interesting from the storage process point of view.

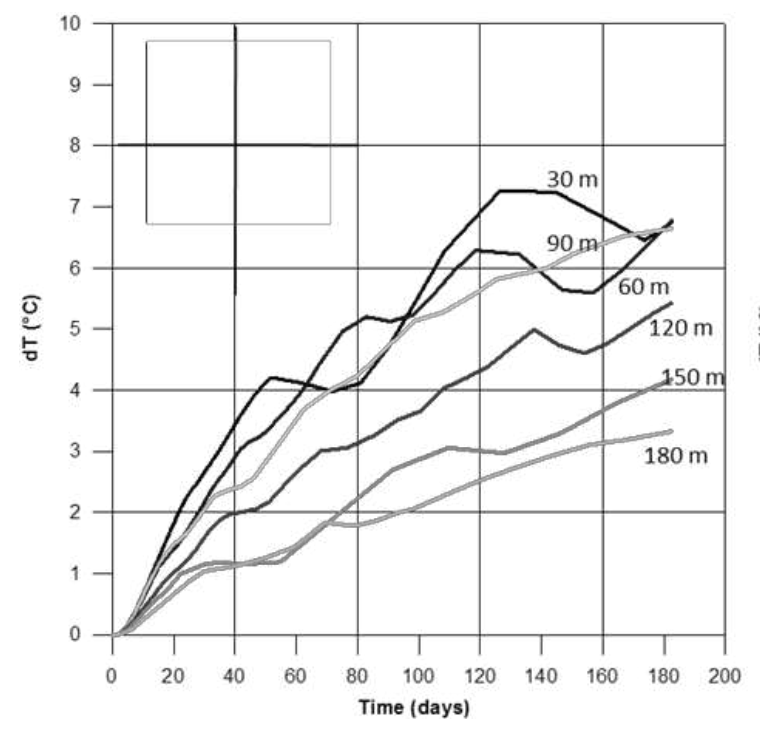

(a)

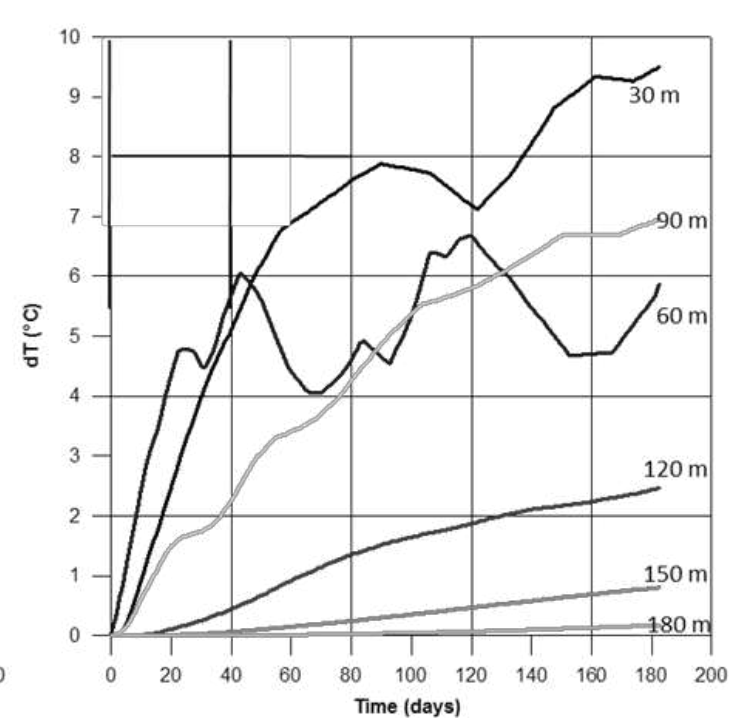

(b)

Figure 8: Temperature evolution in the ground at different depths at the centre of the triangle defined by the three geothermal probes. The injection scenario assumed a six-month injection period with the heat rate equitably distributed amongst the three boreholes. a) case of vertical boreholes; $b$ ) actual SOLARGEOTHERM case (deflected boreholes). 
In reality, it is difficult to drill perfectly vertical boreholes especially if geological layers are tilted. In fact, for the SOLARGEOTHERM project, borehole deflection from vertical can be as much as $50 \mathrm{~m}$ at a depth of $180 \mathrm{~m}$, meaning that the distance between boreholes ( $5 \mathrm{~m}$ at the surface) varies from $2 \mathrm{~m}$ to more than $25 \mathrm{~m}$ (Figure 9).

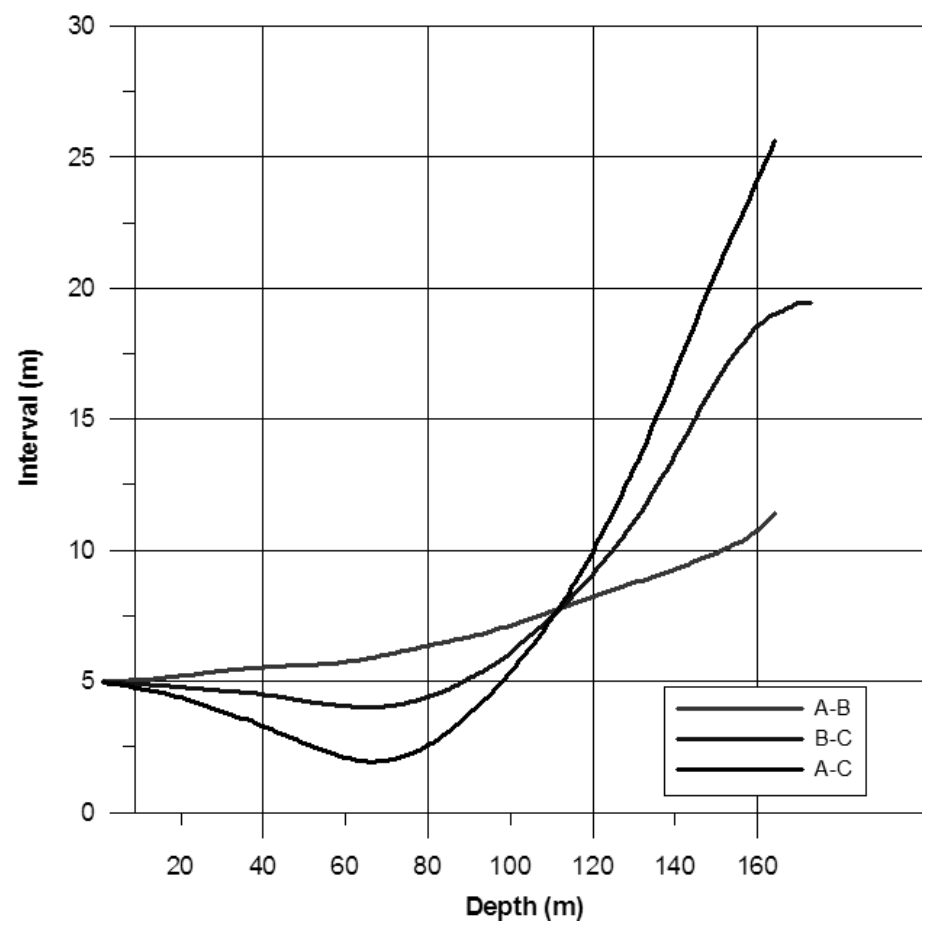

Figure 9: Variation with depth of actual distances between boreholes in the SOLARGEOTHERM experimental device.

For this reason, we performed a second simulation using the actual spacing of the three boreholes which varies with depth. The results are presented in Figure $8 \mathrm{~b}$. The temperature increase in the upper part of the ground storage volume is greater than in the case of perfectly vertical boreholes, with rises of $9.5^{\circ} \mathrm{C}$ at a depth of $30 \mathrm{~m}$, $7^{\circ} \mathrm{C}$ at $60 \mathrm{~m}$ and $6{ }^{\circ} \mathrm{C}$ at $90 \mathrm{~m}$. However, simulation results for the deeper parts of the borehole indicate lower values $\left(2.2,0.8\right.$ and $0.2^{\circ} \mathrm{C}$ at depths of 120,150 and $180 \mathrm{~m}$ respectively). The differences between the two cases are a direct consequence of the spacing of the geothermal probes: the closer the boreholes, the greater the ground temperature increase. The actual spacing at depths of 30,60 and $90 \mathrm{~m}$ is in the range of 2.5 to $7 \mathrm{~m}$, whereas it reaches 8 to $25 \mathrm{~m}$ in the deeper parts. The numerical results suggest that, in the SOLARGEOTHERM context, the maximum efficient depth for energy storage with three injection boreholes would be $100 \mathrm{~m}$. 
Deeper, the effectiveness of the device is decreased both by cooling of the HTF and by the distance between boreholes.

Another scenario was simulated: the heat collected through the solar panels was injected into three boreholes over a whole month (it represents $307 \mathrm{MJ}$ ). The natural thermal relaxation of the system was then simulated for another month. The aim of this exercise was to study whether it is possible to store energy in the ground at the scale of one month. Two configurations were simulated: the actual SOLARGEOTHERM geometry and the vertical boreholes. The results obtained for the three depths for which the greatest temperature rises were observed experimentally (i.e. 30, 60 and $90 \mathrm{~m}$ ) are shown in Figure 10 (SOLARGEOTHEM case) and Figure 11 (vertical case). After one month of energy injection into the three boreholes, in the SOLARGEOTHERM borehole configuration the simulated temperature rise is the same at depths of 30 and $60 \mathrm{~m}(2.8 \mathrm{C})$ and is $1^{\circ} \mathrm{C}$ higher than at $90 \mathrm{~m}$. This is not a surprising result as the spacing between the three boreholes is less at 30 and $60 \mathrm{~m}$ than at $90 \mathrm{~m}$ (Figure 9). At the opposite, the temperature rise decrease with depth (from $5.5^{\circ} \mathrm{C}$ at $30 \mathrm{~m}$ to $3.8^{\circ} \mathrm{C}$ at $90 \mathrm{~m}$ ) in the perfect case (Figure 11). Subsequently, after a month without any injection, the temperature increases are no more than 1.5 to $2.2 \mathrm{C}$ in the real case and 2.1 to $3.5^{\circ} \mathrm{C}$ in the perfect vertical configuration. These last values seem more suitable for energy storage applications. We conclude that the configuration of the SOLARGEOTHERM experimental device is not suitable for efficient underground thermal energy storage. Vertical shorter boreholes should be preferred to optimize the efficiency of the device. 


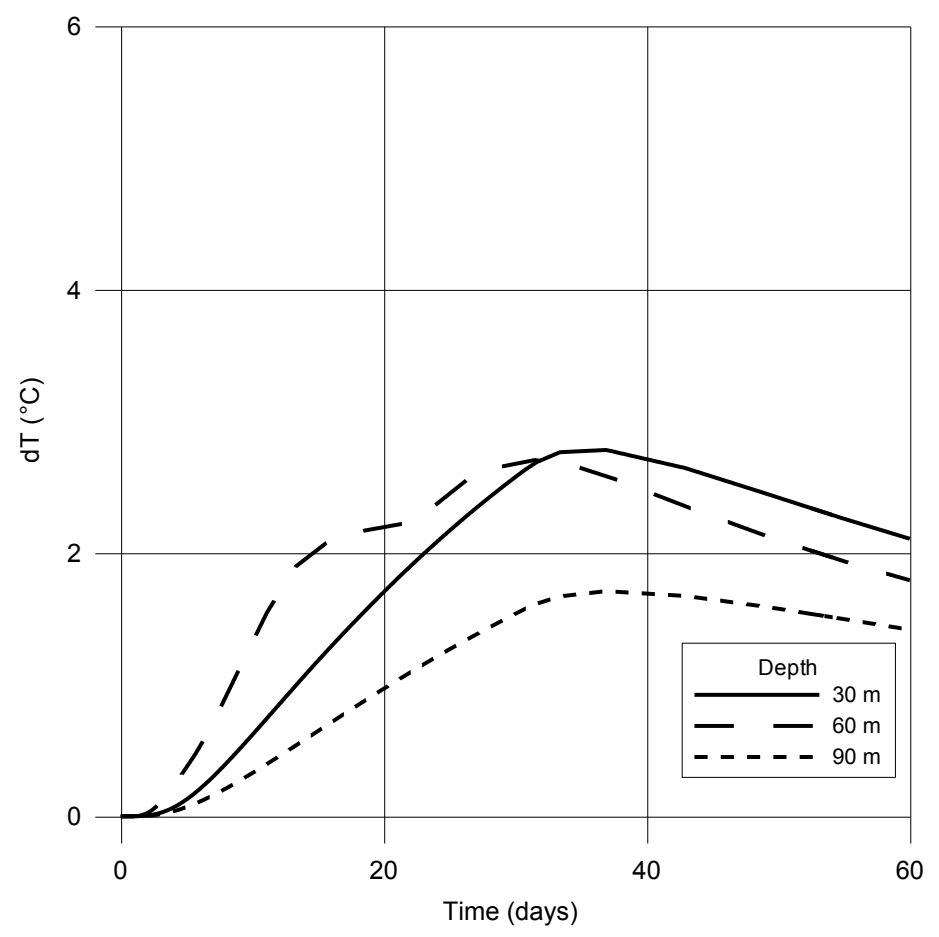

Figure 10: Temperature evolution in the ground at different depths at the centre of the triangle defined by the three geothermal probes of the SOLARGEOTHERM device. The injection scenario assumed a one-month injection period and a one-month without injection period.

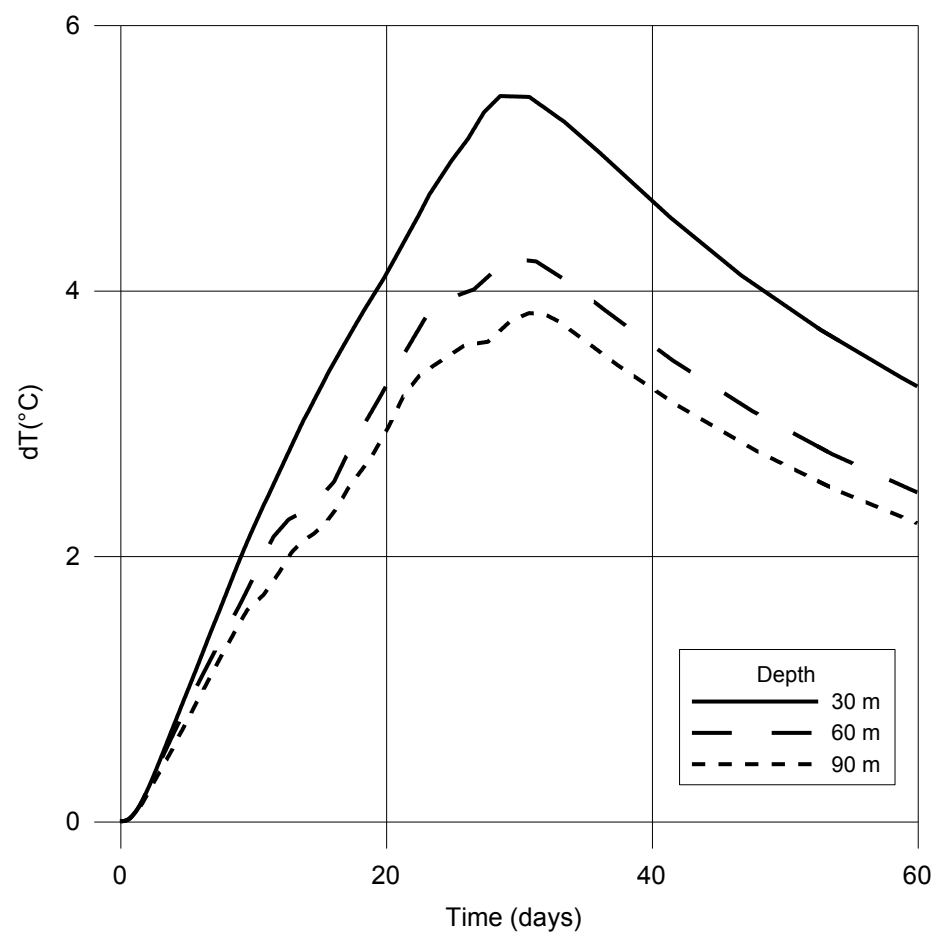

Figure 11: Temperature evolution in the ground at different depths at the centre of the triangle defined by three vertical geothermal probes. The injection scenario assumed a one-month injection period and a one-month without injection period.

Experimental observations have already indicated that hardly 5 per cent of the energy injected during the day is stored in the BTES, the major part being dissipated during the night (Figure 3). The numerical results extend this observation: in the 
experimental context, the heat injected during a given storage period dissipates into the ground surrounding the borehole during the same time period.

\section{Discussion}

Previous experimental and modelling results have shown that, for the heat range investigated, the BTES configuration with three $180 \mathrm{~m}$-deep boreholes could be of interest for storage over a few days but would not be efficient for seasonal storage. Furthermore, it appeared that the deepest BTES are not necessarily the most efficient. In fact, HTF temperature in the geothermal probe decreases with depth and, in our experimental context, the heat rate at over 100 to $150 \mathrm{~m}$ is too low to heat the surrounding ground, of which the temperature is already increased by the geothermal flux. As drilling costs are proportional to borehole depth, evaluation of the depth and design of a BTES that optimise the ratio between heat storage and cost is a worthwhile exercise. A theoretical analysis is therefore proposed, below, to provide recommendations for heat store design. It is based on analytical calculation and minimisation of heat losses in a cylindrical heat store.

A field of vertical geothermal probes defines an underground storage volume, as long as influence radiuses of boreholes intersect. Generally, spacing between 2.5 and $5 \mathrm{~m}$ are investigated [3]. However, other concerns such as maximum temperature increase in the storage volume or practical drilling conditions are to be considered to define the optimal distance between boreholes when designing a BTES. Heat losses from underground thermal energy stores (excluding ATES) are mainly associated with conductive heat transfers from the storage volume to the surrounding rock. For a given storage volume $\left(V_{0}\right)$, the easiest way to reduce heat losses is therefore to minimise the heat exchange surface area (S) between the heat store volume and the outside environment. The heat store may be insulated at its top, as it is the case, for instance, for the operational $63,360 \mathrm{~m}^{3}$ BTES at Neckarsulm (Germany), which is thermally insulated with a $200 \mathrm{~mm}$ layer of polystyrene and covered by 2-3 $\mathrm{m}$ of soil [16]. Once the top is insulated, the exchange surface is limited to the borehole sides and bottom. If we consider that the geothermal probes are located in the ground in such a way that they define a cylindrical storage volume (radius $R$, height $h$ ), it is easy to prove that the top-insulated, cylindrical heat storage volume for which heat losses are minimal is one with its height equal to its radius. Its form factor $E(E=D / h)$ is equal to 2 . 
Below, we compare the time required by two different cylindrical BTES to dissipate a given amount of heat, knowing that the amount of heat dissipated during a time $\tau$ is equal to the integrative sum of the conductive flux $(\varphi)$ between the heat store volume and the surrounding rock. We consider two fields of top-insulated, vertical geothermal probes defining two underground heat stores with the same volume $\mathrm{V}$ but with different form factors $\left(E_{A}\right.$ and $\left.E_{B}\right)$ and exchange surfaces $\left(S_{A}\right.$ et $\left.S_{B}\right)$. For the purposes of the demonstration, the rock is assumed to be a semi-infinite homogeneous porous medium with a uniform initial temperature $\mathrm{T}_{\mathrm{i}}$. The heat store is maintained at a constant temperature $T_{0}$, and heat transfers between the storage volume and the surrounding rock are assumed to be unidirectional (horizontal). With these hypotheses, the ground temperature is given by:

$T(x, t)-T_{0}=\left(T_{i}-T_{0}\right) \cdot \operatorname{erf}\left(\frac{x}{2 \sqrt{a t}}\right)$

where $a=\frac{\lambda^{*}}{(\rho C)^{*}}$ is the equivalent thermal diffusivity of the porous media. The conductive heat flux between the BTES and the surrounding rock is then expressed as: $\varphi_{x=0}=-\lambda^{*} \cdot S \cdot\left(\frac{\partial T}{\partial x}\right)_{x=0}=\left(T_{i}-T_{0}\right) \cdot S \cdot \sqrt{\frac{\lambda^{*} \cdot(\rho C)^{*}}{\pi \cdot t}}$

Hence, for two devices dissipating the same amount of heat, we can write:

$\int_{0}^{\tau_{A}} \varphi_{A} \cdot d t=\int_{0}^{\tau_{B}} \varphi_{B} \cdot d t \Leftrightarrow\left(\frac{\tau_{A}}{\tau_{B}}\right)=\left(\frac{S_{B}}{S_{A}}\right)^{2}$

Expressing the exchange surface of the cylindrical devices in terms of their storage volume and their form factor: $S=\pi \cdot(0.25+1 / E)\left(4 . E . V_{o} / \pi\right)^{2 / 3}$

Finally, from equations 5 and 6 :

$\left(\tau_{A} / \tau_{B}\right)=\left[\left(E_{B} / E_{A}\right)^{2 / 3} \cdot\left(0.25+1 / E_{B}\right) /\left(0.25+1 / E_{A}\right)\right]^{2}$

This last relation enables comparison of the performance of two fields of vertical geothermal probes as underground thermal energy storage devices. For instance, it is applicable for comparison of any cylindrical BTES with a form factor $E_{A}$ to an optimised device with the criterion $E_{B}=2$ (Figure 12). The form factors of the SOLARGEOTHERM experimental device and those of three operational sites described in the literature are shown on the graph. The single, vertical, $180 \mathrm{~m}$ deep geothermal probe is far from the optimised heat store design. The characteristic 
storage time of this device is hardly 13 per cent of the optimum, meaning that, with an optimal heat store design, more than 45 days would have been necessary for the temperature to recover its initial state after a long injection period (against six days in the experimental conditions as shown in Figure 2). Lundh \& Dalenbäck [3] have stated that, as the Anneberg store is fairly small, the heat losses were assumed to reach 40 per cent. The dimensions of the DLSC system in Okotoks [4] and those of the Neckarsulm system [10] are close to the optimum ratio $(\mathrm{D} / \mathrm{h}=2)$, and heat losses are reduced. These BTES are accordingly operating successfully for thermal energy seasonal storage.

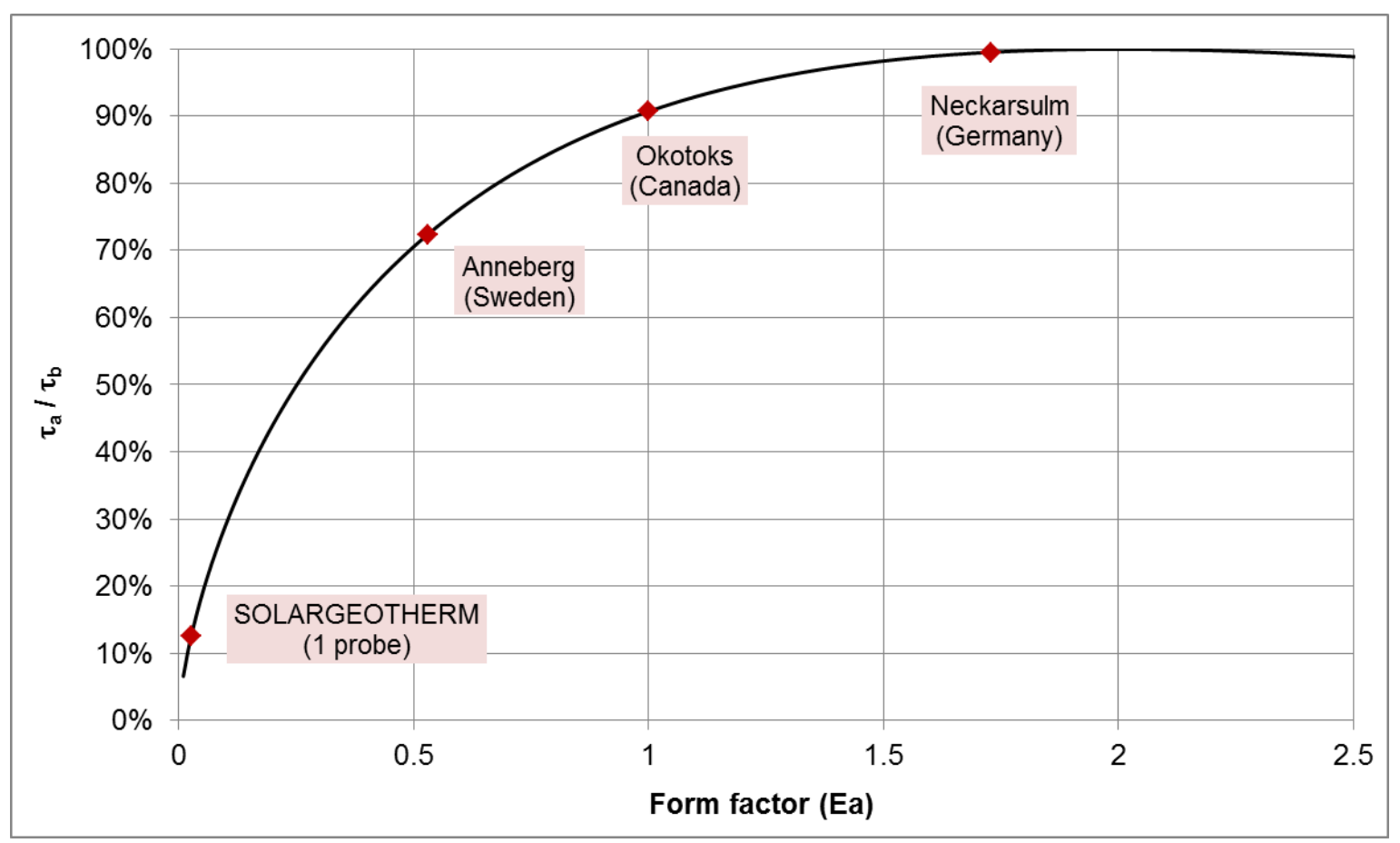

Figure 12: Characteristic heat storage time ( $\tau$ a) of a BTES according to its form factor compared to the characteristic time of an optimised BTES $(\tau b)$ with a form factor of 2 . Positions corresponding to some documented operational BTES are shown on the graph.

\section{Conclusion}

Analysis of the experimental data from the SOLARGEOTHERM project indicates that the major part of the heat injected via a single $180 \mathrm{~m}$ deep borehole is quickly dissipated into the surrounding rock. More precisely, 95 per cent of the heat injected into the geothermal probe over a day is dissipated into the surrounding rock during the following night. It has therefore been concluded that a single borehole is efficient for neither inter-seasonal nor day/night underground thermal energy storage. A 1D analytical model based on energy balance was proposed to estimate the vertical distribution of HTF temperature in the borehole. The model indicated that the HTF 
flowing down the geothermal probe had lost 15 per cent of its energy at a depth of $100 \mathrm{~m}$ and 25 per cent at $150 \mathrm{~m}$. A 3D multilayer numerical model was then developed and validated using the SOLARGEOTHERM experimental data. This model was used to simulate different BTES configurations over a number of years. The numerical results suggest that, in the geological context of the SOLARGEOTHERM project, the maximum efficient depth for energy storage with three injection boreholes would be $100 \mathrm{~m}$. Deeper, the efficiency of the device is reduced both by the cooling of the HTF in the probe and by the distance between boreholes, which may increase considerably with depth if the boreholes are deflected. The simulations also showed that, in the experimental site context, the heat injected during a given storage period is dissipated into the ground during the same time period. Lastly, a theoretical approach to optimising BTES design was proposed. A relation (Eq4) was derived to evaluate BTES performance, enabling comparison of the characteristic storage time of any vertical BTES to that of an optimum one, i.e. a top-insulated, cylindrical heat storage volume with its height equal to its radius.

Based on these experimental, modelling and theoretical results, guidelines can be formulated for vertical borehole field design to optimise underground energy storage:

- Whatever the number of boreholes, their spatial distribution should define a cylindrical volume with a diameter twice its height.

- The depth of boreholes should not exceed $100 \mathrm{~m}$, and they should be drilled as vertically as possible to maintain a constant distance between boreholes (around $5 \mathrm{~m}$ ).

- The upper surface of the heat store must be thermally insulated to reduce heat losses to the atmosphere.

In a favourable geological context, BTES are well suited for inter-seasonal heat storage if their design follows at least these few simple recommendations.

\section{Acknowledgements}

This study was conducted as part of the SOLARGEOTHERM research project cofunded by the French Research Agency (ANR) under the Stock-E 2007 programme. The authors also thank Dominguez Energy for the setup of the experimental device. 


\section{References}

[1] T. Schmidt, D. Mangold, H. Muller-Steinhagen, Central solar heating plants with seasonal storage in Germany, Solar Energy, 76 (1-3) (2004) 165-174.

[2] J.O. Dalenback, Large-scale solar heating and cooling systems in Europe, Proceedings of ISES Solar World Congress 2007: Solar Energy and Human Settlement, Vols I-V, (2007) 799-803.

[3] M. Lundh, J.O. Dalenback, Swedish solar heated residential area with seasonal storage in rock: Initial evaluation, Renewable Energy, 33 (4) (2008) 703-711.

[4] B. Sibbitt, D. McClenahan, R. Djebbar, J. Thornton, B. Wong, J. Carriere, J. Kokko, The Performance of a High Solar Fraction Seasonal Storage District Heating System - Five Years of Operation, Energy Procedia, 30 (2012) 856-865.

[5] X.Q.Zhai, Y.Yang, Experience on the application of a ground source heat pump system in an archives building, Energy and Buildings 43 (2011) 3263-3270

[6] H. Fujii, H. Okubo, K. Nishi, R. Itoi, K. Ohyama, K. Shibata, An improved thermal response test for $U$-tube ground heat exchanger based on optical fiber thermometers, Geothermics, 38 (4) (2009) 399-406.

[7] Acuna J, Distributed thermal response tests - New insights on U-pipe and Coaxial heat exchangers in groundwater-filled boreholes, Doctoral Thesis in Energy Technology, Stockholm, Sweden (2013)

[8] S. Lanini, D. Nguyen, Caractérisation de l'hétérogénéité verticale des propriétés thermophysiques du sous sol par deux tests de réponse thermique, in: GFHN 2010, Louvain-la-Neuve (Belgique), 2010.

[9] F. Delaleux, X. Py, R. Olives, A. Dominguez, S. Lanini, D. Nguyen, Supervised rock-mass storage of thermal energy produced by a solar thermal panel, in: SOLAR PACES 2010, Perpignan (France), 2010.

[10] J. Nussbicker, W. Heidemann, Monitoring results and operational experiences for a central solar district heating system with borehole thermal energy store in Neckarsulm (Germany). , in: ECOSTOCK 2006, NJ USA, 2006. 
[11] L.Lamarche, B.Beauchamp, A new contribution to the finite line-source model for geothermal boreholes, Energy and Buildings 39 (2007) 188-198

[12] D. Bauer, W. Heidemann, H.J.G. Diersch, Transient 3D analysis of borehole heat exchanger modeling, Geothermics, 40 (4) (2011) 250-260.

[123] D. Mottaghy, L. Dijkshoorn, Implementing an effective finite difference formulation for borehole heat exchangers into a heat and mass transport code, Renewable Energy, 45 (2012) 59-71.

[14] I.Sarbu, C.Sebarchievici, General review of ground source heat pump systems for heating and cooling of buildings, Energy and Buildings 70 (2014) 441-454.

[15] D. Pahud, B. Matthey, Comparison of the thermal performance of double U-pipe borehole heat exchangers measured in situ, Energy and Buildings, 33 (5) (2001) 503-507.

[16] J. Nussbicker, D. Mangold, W. Heidemann, H. Mueller-Steinhagen, Solar assisted district heating system with duct heat store in Neckarsulm-Amorbach (Germany). , in: ISES Solar World Congress 2003, Goeteborg (Schweden), 2003. 